\author{
(online) $=$ ISSN $2285-3642$ \\ ISSN-L = 2285 - 3642 \\ Journal of Economic Development, Environment and People \\ Volume 2, Issue 4, 2013 \\ URL: $\underline{\text { http://jedep.spiruharet.ro }}$ \\ e-mail: office jedep@spiruharet.ro
}

\title{
Sustainable Economic Development in the Transition Countries, With a Retrospect of the Republic of Macedonia
}

\author{
Prof. Aleksandar Nikolovski, PhD, Prof. Mirko Tripunovski, PhD, \\ Prof. Gjorgji Tonovski, PhD \\ FON University, Skopje, Macedonia
}

\begin{abstract}
.
Sustainable development represents a civilization challenge that should meet the needs of today's generations without jeopardizing the ability of the Earth to meet the needs of the future generations. This challenge, as an evolutionary process in which the social and economic development and the environment protection are independent, but mutual complementary components demands the solving of several issues

The vision of sustainable economic development is based on the historical, cultural and political development of the countries. There is no unique way of sustainable development for different countries and therefore they cannot be made in the same way.

The transition toward sustainable development represents a social choice that connects the global vision of the local needs and goals. The citizens must participate in the process of sustainable development. They must recognize the role they have in creating problems and finding solutions.

In order to gain a general frame for the assessment of sustainable economic development it is necessary to integrate several methodologies and approaches toward the possible future generations for a quality and healthy life.

One of the ways of assessing the results from the policies and the activities is the use of the principles and indicators according to which it is determined how much the countries work on sustainable development. Parts of the indicators are generally accepted, and part are in a modeling phase. A systematic approach is necessary to see whether all indicators are necessary, and which of them are necessary for the assessment of sustainability. The economists do not have problems in executing the objective and quantitative indicators. The sociologists are facing many problems in the execution of indicators because of the immateriality of the life quality. However, the environment experts see problems when they are limited in the execution of indicators.

Sustainable development is much more than a mutual connection between the economy, the law and the ecology in establishing relations between the indicators of sustainable development and the economic development are the basis for creating conceptual link between the different approaches toward sustainable economic development.
\end{abstract}

The aim of this paper is the implementation of today's relevant experiences, practices and theoretical knowledge expressed through the changes that are reflected in the life in the Republic of Macedonia:

- Protection of natural resources

- Sustainable production and consumption

- Sustainable sources of energy and

- Following and reporting about the conditions, supported by the following indicators:

- Level of citizens' involvement in the social activities

- Number of companies that have an ecological strategy

- Number of people involved in the planning process

- Number local communities in the Republic of Macedonia, which are eco-logically oriented 


\author{
(online) $=$ ISSN $2285-3642$ \\ ISSN-L = 2285 - 3642 \\ Journal of Economic Development, Environment and People \\ Volume 2, Issue 4, 2013 \\ URL: http://jedep.spiruharet.ro \\ e-mail: office jedep@spiruharet.ro
}

- Number of shops that sale home food and organically developed food

- Number of companies for organic production

- Renewable sources of energy in the Republic of Macedonia

- The level of nitrogen dioxide in the atmosphere

The elaboration of the final material will go through the following principles: Participation of local citizens. Key segment of the implementation of the Agenda 21; Short-term plans that support the municipalities that environmentally oriented; Local production, which is forced whenever possible;

The oil, coal, gas, water should be saved and renewable sources of energy should be used instead.

Keywords: sustainable development, economic development, transition, process of evolution, changes, indicators, principles, natural resources, sustainable production, sources of energy.

JEL Codes: O, 013, Q01

\title{
1. Introduction
}

The sustainable development is the fundamental goal of the European Union. This concept is one of the main aims of the European integration. Sustainable development is not just about protecting the environment. It is about securing economic growth, social cohesion and protection of environment, which go hand in hand. This is the core of the European model of society that we want to strengthen and preserve for the following generations. The economic, social and the goals of the environment are not contradictory, there are complementary. The strategy for sustainable development is essential for securing balanced, righteous and sustainable society in Europe. We Europeans are rightfully proud of our social model, but we have to modernize it, so that it can be functional for the future generations. It must become a model that we can offer with pride to the rest of the world. At the end, the future or the planet depends on the global sustainable development, and the best way to promote it is for Europe to practice that what it declares and to lead by setting an example ${ }^{1}$.

\section{Economic parameters of sustainable development}

The economic parameters of sustainable development should be aimed toward several aspects. However, together with the sustainability of the development, as an economic category, there are three aspects that occur and through which the sustainable development, as well as the sustainable usage of renewable and unrenewable resources should be proportioned. Here I will list its main aspects:

- Economic development opposed to sustainable development;

\footnotetext{
${ }^{1}$ Romano Prodi, President of the European Commission, European Parliament, Strasburg, 2001.
} 


\author{
(online) $=$ ISSN $2285-3642$ \\ ISSN-L = $2285-3642$ \\ Journal of Economic Development, Environment and People \\ Volume 2, Issue 4, 2013 \\ URL: $\underline{\text { http://jedep.spiruharet.ro }}$ \\ e-mail: office jedep@spiruharet.ro
}

- Financial support for the abstention of economic development, as an advantage to the sustainable development;

- The usage of natural renewable and unrenewable resources as a material dimension.

These three aspects are positioning the economic dimension that determines the sustainable development, not just in the context of creation of political attitudes regarding the environment, but as well in the context of all economic, social and environmental parameters. This determines the promotion of the economic and social advancement of the citizens, where as the basis we take the principle of sustainable development. However, this creates a model for mutual approach and integration that is based on mutually supportive parameters for stabile economic growth, social development and environment protection.

The economic parameters for sustainable development must be based on the developmental program, which will be aimed at achieving:

- Political stability of the development; safe economic conditions; social cohesion; and sustainability of the environment.

On the ground of the above stated economic parameters for sustainable development, it is necessary to include percentages that will give dimension to the procedure of preparing national strategy for sustainable development and thus through:

- Assessment of the influence the sustainable development has on the domicile economy;

- Creating strong internal coordination between the ministries, the sectors and the state institutions;

- Development of national plans for sustainable development.

The contribution of each economy on the sustainable development is to follow the global characteristics through establishing wide-ranging and integrated collection of activities and their establishing. These activities mainly encompass the three mutually connected components of sustainable development:

- The economic component of sustainable development;

- The social component of sustainable development; and

- Environment.

In order to fulfill the tasks of the three mutually connected components, few preconditions are necessary for the implementation of the same parameters:

- Increased coherence in the approach;

- Improved management, leadership;

- Increased financial resources for the implementation of the necessary sustainable development;

- Development of leading structural indicators for sustainable development (headline);

- Managing natural resources.

The analysis of the abovementioned goals raises a significant question: What should be done regarding all these issues, all these directions, how should they be implemented up to different degrees by the national economies, and this partially because of the different starting positions, and partially because 


\author{
(online) = ISSN $2285-3642$ \\ ISSN-L = 2285-3642 \\ Journal of Economic Development, Environment and People \\ Volume 2, Issue 4, 2013 \\ URL: $\underline{\text { http://jedep.spiruharet.ro }}$ \\ e-mail: office jedep@spiruharet.ro
}

different levels of reluctance to accept the changes? However, the Republic of Macedonia signed the Stabilization and Association Agreement with the European Union, where in article 80, paragraph 2, page 42 is clearly stated: The policy and other measures should aim at establishing economic and social development of the Republic of Macedonia. This kind of policy should form the start care that the environment is incorporated and connected with the demands for steady social development. With this the Republic of Macedonia made a determination for economic and social development and care about the environment, which main aspect would be the securing of sustainable development.

The sustainable development as a process must rest on the basic civil rights and civil society, be compatible with the human rights and duties, depending on the social status, education, age, sex, culture etc. In this context, the sustainable development must the product of economic development, social development and environment protection, of their mutual interdependency and achieved compatibility.

The respect toward human rights and freedoms, within the democratic processes, as the basis for development, publicly and responsibly manages all sectors and resources of the state, the open partnership and efficient participation of the citizens in the public life, with a necessary dose of personal and collective responsibility and interactive behavior of the second dependent factor for establishing a process of sustainable development of renewable and unrenewable natural resources.

Basically, the sustainable development must be defined as an economic development, which is environmentally acceptable, at the same time socially responsible and timely established with clearly planned usage of natural resources, as a basic pillar, around which responsibly and solidly gravitate citizens, with environmental sense, management and knowledge about healthy environment and applicable sustainable development.

The elaboration i.e. the range of the sustainable development demands active attitude towards all actors of the open partnership, regarding the realization of a big project, which determines the right place and relation in the home economy of each participant, but also within the global strategies that lead the world family of states toward the realization of special projects which will be the foundation stone for the future integration of the Republic of Macedonian in the EU. The elaboration, implementation and introduction to the democratic public of the achieved results must go in the following directions, where the dominant role for establishing sustainable development will fall on areas such as:

- Economic and technological sustainable development; Protection and promotion of the environment; Concentration and exploitation of natural resources; Demographic processes, development, management of human resources; Social security, health protection; Local and regional development; Legal and administrative measures for sustainable development; Sustainable development education; Public and medium availability regarding the sustainable development.

The issues and tasks that arise in front of all actors of the social development in the creating a society with sustainable development can be demensionalised in several areas, such as: the economy of the Republic of Macedonia in a state of foreign transition, financial markets, quantitative and qualitative analyses, quality of the economic and human development. The relevant indicators, through which we can 


\author{
(online) = ISSN $2285-3642$ \\ ISSN-L = 2285-3642 \\ Journal of Economic Development, Environment and People \\ Volume 2, Issue 4, 2013 \\ URL: $\underline{\text { http://jedep.spiruharet.ro }}$ \\ e-mail: office jedep@spiruharet.ro
}

see and process the sustainable development, are expressed in four points of economic, environmental, social and institutional indicator. Determinates that determine the sustainable development are: the nature, righteousness and future:

The nature any production system should be considered as its integral part and not be treated as a free asset. The production systems are connected in a material chain and the first production system always gets a raw material from the environment.

The righteousness is a second important determinant in the sustainable development that determines the place of the producers, as well as of the consumers regarding the exploitation of natural resources. The righteousness demands returning of all elements used from the nature in increased levels for the development of our own economies, through finical support of the economies that are in stagnation and the social stratification is strengthen, as well as the health and environmental problems. The principles number 5 from the Declaration from Rio emphasizes that all states and all people must cooperate in respect of the important tasks for eradication of poverty, as a necessary prerequisite for sustainable development in order to reduce the differences in the standard of living and to better suit the needs of most people in the world.

The future as a determinate of the sustainable development calls upon the society, the companies, the managers and individuals to take regard of the time to come. This especially applies to businesses that in the race for efficiency, effectiveness, competitiveness and profitability, forget about the future and the sustainable development. The developmental policies must be proactive instead of reactive.

\title{
3. The concept of sustainable development
}

During the last decade the concept of sustainable development started to attract the attention of the scientific and wider public. Because of the long-term harmonization of the economical processes and the tempo of the processes in the environment, the concept of sustainable development is understood as a development that is in accordance with today's possibilities and needs, without harming the needs of future generations.

The appearance of the concept of sustainable development is a consequence of the collected information in the area of natural sciences that find their application in the economic processes. An example is the size and rate of the material and energy. There is a shortage of the so called existential theorem in the economy and the environment. This is especially noticeable during the maturation of the sense for subtle mixture of determining parts.

The living organism, among which the human, are becoming more and more interested is the reason for their natural surroundings. Therefore, the development in the area of economy represents a process that is adjustable to the demands of the environment.

The science gives compromises for the sustainable development in the form of indirect insisting regarding the real meaning of the term development. The same cannot be understood as a single and unique type of growth. 


\author{
(online) = ISSN $2285-3642$ \\ ISSN-L = 2285-3642 \\ Journal of Economic Development, Environment and People \\ Volume 2, Issue 4, 2013 \\ URL: $\underline{\text { http://jedep.spiruharet.ro }}$ \\ e-mail: office jedep@spiruharet.ro
}

This applies most of all to the structural principles in the economic sphere, but also in the society as a whole, which are brought by the economic development. Also other latent advantages that are result of the economic growth (in the area of social welfare) are emphasized, not just the growth of income per capita. That actually regards the issue about the scope of the term standard of living, of course by insisting on its wider exploitation, i.e. it clear that it cannot be defined in a single way just as a real income per capita ${ }^{2}$.

The practical approach and realization of the concept of sustainable development from the aspect of environment management demands showing respect for two principles, accepted as basic, that should always be respected:

- Using independent renewable functions of the environment as sources of resources, this should be developed according to regenerating principles of specific natural resources;

- Maximizing the optimality and rationality in the exploitation of unrenewable natural resources;

The concept of sustainable development is moving toward the exploitation of the permanent reserves of natural resources and the environment's power of absorption. Specific digressions are also appearing regarding the basic premises of the concept. The concept also has a weak side. That is in a way a second premise. A potential argument regarding the viability of the concept is noticeable. The demands regarding the integration righteousness of the concept of sustainable development could not be met by conventional theory of utilitarism. According to the libertarians, as supporters of the free will, they cannot answer the requested principle of sustainability. According to them each activity is justified if is legally based. Today's generations can use the use the environment in the most acceptable way.

The future is always subjected to depreciated attention because of the fact that future generations hold only a temporary position in view of the current generations. On the other hand, current generations always pay greater attention to fulfilling their own needs and they know very little or at all about the needs of the future generations ${ }^{3}$.

Specific remarks can be made regarding the implementation of integration righteousness. All people have the right to equal treatment. The basic human needs should be pleased.

The degree to which future generations can be compensated for the damages from the present is very relative. This is because the damage cannot be fully revoked. The usual economic approach in this respect is traced upon the thought of Jeremy Bentham how believed that damage would be reversible with the

\footnotetext{
2 David W. Pearce. Kerry R. Turner. Ibid., p. 43.

${ }^{3}$ Subjective depreciation of the future in comparison to the present in the eyes of every men is a fact to which even $A$. S. Pigou. He clearly point that for people the present has a greater value than the future. This comes from the fact that satisfaction of a specific need in the present is much more real the same in the future. Therefore, the ever present dose of uncertainty, when analyzing future development trends, should not be surprising, and in that context the concept of sustainable development.
} 


\author{
(online) = ISSN $2285-3642$ \\ ISSN-L = 2285-3642 \\ Journal of Economic Development, Environment and People \\ Volume 2, Issue 4, 2013 \\ URL: $\underline{\text { http://jedep.spiruharet.ro }}$ \\ e-mail: office jedep@spiruharet.ro
}

help of the good ${ }^{4}$. Hence, the Pareto Criterion allows for creating damage (in this case pollution), but immediately afterwards there should be compensation by relocating the resources. It is clear that the damage and the compensation in this case are seen as equal. However, if put the simple mathematical calculus aside, it is clear that from moral aspect this must not always be the case. On the contrary, the damage remains despite the good done, and the good cannot justify the damage. If individuals pay in order to have straight road that would spare two lives a year, then it inconceivable to think that by killing one motorcyclist a year can simply be perceived as an improvement ${ }^{5}$.

This problem is mostly found in cases when there is involvement of the right to live, but his can be expended in other situations as well. However, here arises an implicit argument that very often provokes flaming discussions regarding the paternalism from the government ${ }^{6}$.

In this way the concept of sustainability can be placed on the terrain of righteousness between the generations (present and future). Future generations can be put in situation to deal with endangered environment, as a result of the activities of the present generations, where the degree of disruption of the equilibrium can reach the extent of no reparation. In order to evade such situations, as optimal can be accepted the so called agreed approach, which actually represents hypothetical agreement between the current and future generations regarding a behavior toward the environment that will be obligatory for all, and will be based on John Rawls idealized model of decision making, coming from his veil of ignorance. Rawls's veil of ignorance does not allow the rational individuals, representatives of the modern social communities to discover their own privacy on separate levels, creating in this way preconditions for reaching fair decisions. Still it seems that this kind of decision making is not based on firm foundation. The dual nature of the Rawls's theory, the righteousness as a rational cooperation and the righteousness as a universal hypothetical agreement, arouses conflict as soon as the analysis is moved forward from the modern social societies. In the context of integration, if all generations are represented in their original position, then the representatives themselves could calculate how many generations will there actually be. However, this is one of the questions that to some point depend on their reasoning ${ }^{7}$.

The striving toward a higher standard of living, as an imperative of the future, as a final limit, in the sense of better life for future generations is constant. The issue of violating the right of the future generations is constantly present. The institutional circumstances are those that determine the frames of establishing rights and raising the issue of damage compensation. The graduate relaxation of the scientific

\footnotetext{
${ }^{4}$ Clive L. Spash. "The political Economy of Nature". Review of Political Economy, volume 7, Number 3, July, 1995, p. 282.

${ }^{5}$ Clive L. Spash. Ibid., p. 282.

${ }^{6}$ This often promoted thesis by the critics of the regulation, according to which each state with its behavior manifests signs of "concerned parent" for its children (in this case citizens), constantly averting them from a specific activity.

${ }^{7}$ David W. Pearce. Kerry R. Turner. Ibid., p. 236.
} 


\author{
(online) $=$ ISSN $2285-3642$ \\ ISSN-L = 2285-3642 \\ Journal of Economic Development, Environment and People \\ Volume 2, Issue 4, 2013 \\ URL: $\underline{\text { http://jedep.spiruharet.ro }}$ \\ e-mail: office jedep@spiruharet.ro
}

thought is in line with the natural laws as limiting elements. The future is in the resources of goods and services. In this way we can reach a full appreciation of the individual personalities and the affirmation of their individual preferences.

Each generation should leave to the future generations a healthy environment, not just through preserving the resources, but also through furthering the technology and innovations. In this way we will slow down the reduction of resources, we will protect the environment from pollution and have easier approach to new resources.

\title{
4. Conceptual link between the principles and indicators- research
}

Sustainable development is much more than a mutual connection between economy, law and ecology, in the determining of relations between the indicators of sustainable development and economical growth it is the basis for creating a conceptual link between the different principles that in the research conducted by Prof. Mirko Tripunovski in 2005 conducted on 1200 respondents, confirmed with more than 200 identical responses are explained through the following analysis:

Following the principle that the participation of the local citizens is crucial for the implementation of the Agenda 21, we are analyzing the indicator for the level of involvement of the citizens in the social activities of R. Macedonia.

According to the Agenda 21, the development must be sustainable and most of the activities of the Rio Earth Summit in 1992 should be implemented on a local level, through the cooperation of individuals, the social and local government. The success of the whole process is achieved through the involvement of the local population that states its own agenda, which could probably happen in an active, dynamic society where local opinion is valued. According to the researches of the population of the R. Macedonia it can be concluded that there is a small change in the number of people that are actively involved in social activities, with $35 \%$ fairly involved in the local activities. Most of them, one fourth are involved in charity work, while one fifth are members of the local interest groups.

The issue of how people communicate in local societies is considered very important, as a positive effect on people's health and their existence. According to the research, designed to measure how much people are kind to their neighbors, three fourths of the people believe in their neighbors and help each other and most of the population want to and feel good living in their neighborhoods. West and east of Macedonia are considered as a negative example and antagonism of economic and rural development.

The short-term plans should have a positive impact on the long-term ones, as a principle it determines the indicator, what is the number of companies that have an environmental strategy.

The business has a big role in the local society and as such it can have a great influence in order for the society to be stabile. As a result of the need to plan ahead, the sustainability demands from the organizations to try to minimize their negative effects on the environment. One way of achieving this is to form and adapt to the environmental strategy. There are also long-term plans that measure the potential impact of the activities and enable a set of "rules" that can help in reducing that impact. For example, the 


\author{
(online) $=$ ISSN $2285-3642$ \\ ISSN-L = $2285-3642$ \\ Journal of Economic Development, Environment and People \\ Volume 2, Issue 4, 2013 \\ URL: $\underline{\text { http://jedep.spiruharet.ro }}$ \\ e-mail: office jedep@spiruharet.ro
}

obligation of buying goods from the local distributors will influence the reduction of transport and packing, as well as on the support of the local business. Very important part of the strategy is that the influence should be measured periodically in order to be sure that the organizations are moving in the direction of sustainability.

Additionally to the flotation of the last 6 years, the percentage of business with environmental strategies has a fall of $6 \%$, which means that less than half of the businesses have adopted those strategies. However, the percentage of food stores that have environmental strategy has a significant increase of $12 \%$. As a result it is hard to say whether it is a positive or a negative step, despite the decline, the percentage of business that have a strategy is higher than those of the food stores. Without looking into the environmental strategies of the companies individually it is hard to estimate whether the level of the company's commitment.

In the period 2000-2011 there were some reactions in Macedonia regarding the indicators through which it had contact to the businesses in the R. Macedonia. Those companies that answered positively received a detailed material that they should implement and execute the environmental policy. Even despite the fact that there is no feedback regarding all this, it is considered that the delivered information regarding the policy is not complicated at all and only a few changes should make dramatic differences in respect of the ecological performance of the companies.

The decision making and the planning should include the local citizens as principle confirms the indicator of how many people are involved in the process of planning and whether the citizens are interested in the involvement.

The democratic processes can be really effective if the people are given divided responsibility for decision making and planning. This participation promotes the sustainability through allowing for a development of closer relations and partnerships within the frames of the municipality and the need of local knowledge can result in the most effective decisions. The centralized planning may not recognize the local needs, culture and tradition and in order to maximize the involvement of the democratic process can be easily acceptable and capable of incorporating the opinions of the municipality and the local selfgovernment.

Since 2005 the percentage the people of the R. of Macedonia that would consider contacting the Municipality Council, Local Community Council, and their local council has increased. $74 \%$ would contact the local self-government, $67 \%$ the local community and $61 \%$ their local council.

The percentage of the local population that thinks that the municipality council, the local community, their local council was really interested in their opinions has increased since 1990. The most important changes happened regarding the local council, from $15 \%$ to $31 \%$ and the municipality council from $19 \%$ to $34 \%$.

It is possible for these indicators to be wrongly interpreted because people strive to come more closely to the authorities regarding the planning of single problems, rather than being involved during the whole planning process of the municipality. 


\author{
(online) $=$ ISSN $2285-3642$ \\ ISSN-L = $2285-3642$ \\ Journal of Economic Development, Environment and People \\ Volume 2, Issue 4, 2013 \\ URL: $\underline{\text { http://jedep.spiruharet.ro }}$ \\ e-mail: office jedep@spiruharet.ro
}

The politicians should support the municipalities that are environmentally oriented as a principle that corresponds to the indicator of the number of local communities in the R. of Macedonia, which are environmentally oriented.

The summit in Rio in 1992 presented the Local Agenda 21 with the recommendations that the local authorities should work with the municipalities in order to create strategies on local level that will collectively oppose to some of the main global problems in respect of the quality of life in the 21st century, such as poverty and climate changes. This has shown to be a problem for many authorities, some have ignored the Agenda 21, some tried to create a strategy with a minimum involvement of the public, while some were involved in some processes of entrepreneurships using innovative techniques in order to involve their municipality. In the R. of Macedonia the process was eased through and independent organization of the municipalities, which had the possibility of setting strategies, indicators and priority actions.

In 2005 it was confirmed that there are no policies for the municipality council or the local community councils that fulfill the clearly defined criteria of sustainability even though specific document, such as the local plan, refer to the problem of sustainability. Up until 201 both authorities recognized the importance of sustainability and that what is made in this respect at the highest level of the corporative plan of the local communities and the strategic plan in the municipality council. Within the following years, the government's reform brought the incorporation of the sustainability principles within the frames of the strategies of the municipality that should be built with a local consultation. The last report about the indicators expressed a concern that this leads to many authorities diverting their recourses from the Local Agenda 21 to the planning process of the municipality, which is supported by a forum of representatives from the state agencies, rather than the municipalities itself. The municipality planning process in the R. of Macedonia should still engage the municipality.

The corporative plan of the local community is now incorporated in the best performance plan of the council and the sustainability is no longer expressed as one of the corporate priorities of the council. Still, all big reports should go through the municipality council in order for their influence on the sustainable development to be investigated.

The local production should be forced whenever possible, as a principle, it seeks an answer to the indicator for the number of store that sells ecologically produced food.

The consumption of the local produced goods helps in the reduction of damage on the environment provoked by the transport, and in the same time it stimulates the growth of the local economy. The great distance of the traveling of food, defined as a destination in which the food travels from the field to the kitchen, is increased with the increase of the demand of different types of food during the whole year. Additionally to the ever more obvious impacts provoked by the transport, the food the travels long is often hard to process, pack or chemically protect. The irony is that many products from this country are simultaneously being imported from other parts of the world. The import from less developed countries can encourage the production of products for profit for the price of the traditional food product. This can lead to negative effects on the economies and the environment of these rural municipalities. 


\author{
(online) $=$ ISSN $2285-3642$ \\ ISSN-L = 2285-3642 \\ Journal of Economic Development, Environment and People \\ Volume 2, Issue 4, 2013 \\ URL: $\underline{\text { http://jedep.spiruharet.ro }}$ \\ e-mail: office jedep@spiruharet.ro
}

Since 2010 the percentage of stores that sell local products has increased and now almost all food stores in the R. of Macedonia sell at least one local product. While some stores emphasized that only some of their goods are local, other, such as the butchers, emphasized that a great percentage from supply is from a local source. Additionally to the local stores, the markets of agricultural products encouraged the producers to sell their goods directly to the consumers in their surroundings.

The activities that pollute the land, water and air should be stopped whenever possible, as principle that analyses the indicator of the percentage of level of the azoth dioxide in the atmosphere.

The quality of air contributes to our health and good condition, as well as for the protection of the biologic al diversity. The people have the right to expect that the air they breathe won't harm them. The hydrogen dioxide ( $\mathrm{HO}_{2}$ ) is the biggest polluter of the atmosphere, where the basic source for it is the road transport. The high levels are a threat to the human health and can increase the production of other polluters, including the low ozone and acid rain.

At the moment $\mathrm{R}$. of Macedonia is monitoring the $\mathrm{HO} 2$ on several places in several cities, because that is the easiest and cheapest indicator that can be monitored.

The activities that pollute the water and air should be stopped whenever possible as a principle we analyze it through the indicator for the number of companies for organic production.

The agriculture has a significant effect on the economic, natural and social environment of the R. of Macedonia. The extent of exploitation of chemicals together with other realizations evoked a significant concern regarding the potential long-term effects of the human health and environment.

Last year the area of organic land in the R. of Macedonia was almost doubled, but we still import 70\% of our organic food compared to the import of $10 \%$ of France. The government demands that the import be reduced to $30 \%$ until 2010 , however the number of organic cultivators that had loses has increased in the last five years, the sustainable agriculture demands creating an action plan in order to achieve this goal, with new payment schemas for the cultivators, new means for researches and supermarket chains should start working with the producers from R. of Macedonia.

The oil, coal, gas, water should be saved as principle it analyses the indicator for renewable resources and sources of energy in the R. of Macedonia.

The nature of the fossil fuels, such as the coal, oil and natural gas, will inevitably be spent and the renewable energy will become part of the main sources of energy in the world. The carbon dioxide and sulfur dioxide are produced when the fossil fuels, such as coal and natural gas, are used and this leads to the world threats for the environment, from global warming to acid air. The extremely long time of the toxic waste decomposition and the fear of accidents in the nuclear power station made the nuclear power controversial alternative source of energy.

The goal of the government is $10 \%$ of the electric energy in the R. of Macedonia to be produced by renewable energy until the end of 2010 . At the moment only $3 \%$ come from renewable sources. R. of Macedonia is the windiest country in Europe and the government allowed for two groups of mountain windmills. Each of them is big enough to produce electricity for more than 50.000 homes of medium size. 


\author{
(online) = ISSN $2285-3642$ \\ ISSN-L = 2285 - 3642 \\ Journal of Economic Development, Environment and People \\ Volume 2, Issue 4, 2013 \\ URL: $\underline{\text { http://jedep.spiruharet.ro }}$ \\ e-mail: office jedep@spiruharet.ro
}

The proposal for two 1.3 MW windmills in Hedfild Shtip, which would have the capacity to produce enough electricity freed from polluters for approximately 1600 homes is still in the planning phase.

\title{
5. Conclusions
}

The short-term plans should have a positive impact on the long-term ones, as a principle it determines the indicator, what is the number of companies that have an environmental strategy.

The decision making and the planning should include the local citizens as principle confirms the indicator of how many people are involved in the process of planning and whether the citizens are interested in the involvement.

The politicians should support the municipalities that are environmentally oriented as a principle that corresponds to the indicator of the number of local communities in the R. of Macedonia, which are environmentally oriented.

The local production should be forced whenever possible, as a principle, it seeks an answer to the indicator for the number of store that sells ecologically produced food.

The activities that pollute the land, water and air should be stopped whenever possible, as principle that analyses the indicator of the percentage of level of the azoth dioxide in the atmosphere.

The oil, coal, gas, water should be saved as principle it analyses the indicator for renewable resources and sources of energy in the R. of Macedonia.

\section{References:}

[1] David W 1.. Pearce. Kerry R. Turner. Ibid., p. 236.

[2] Clive L. Spash. "The political Economy of Nature". Review of Political Economy, volume 7, Number 3, July, 1995, p. 282.

[3] Tripunoski, M. (2006) Održliv razvoJ, upravuvanje i stopanisuvanje so otpad, Evropski Univerzitet, SkopJe.

[4] Armenski, S. (2001) Nekonvencionalni termoenergetski postroJki, NIP Studentski zbor, SkopJe.

[5] Tripunoski, M. (2008) Sovremeni ekološki politiki vo svetot i EvropskataUniJa, FON Univerzitet, SkopJe.

[6] Tripunoski, M. (2010) Menadžment vo stopanstvoto i Javniot sektor, FON Univerzitet, SkopJe.

[7] Tripunoski, M. (2008) Meǵunarodni ekonomski odnosi, sovremeni tendencii, FON Univerzitet, SkopJe.

[8] Tripunoski, M. (2008) Ekonomski principi i analizi, FON Univerzitet, SkopJe.

[9] Tripunoski, M. (2007) GlobalizaciJa, FON Univerzitet, SkopJe. 